\title{
A Suggestibility Prevention Program- Not True, Not One, Not Good, Not Beautiful? Forget About It!
}

Fifty years of information technology has overwhelmed the Church's traditional role as the source of all that is true, one, good and beautiful. Therefore, Original Sin prevails as humans have been proven to be gullible and suggestible about anything if it is packaged sensationally. Suggestibility Prevention Programs can help everyone understand ways to cope with anti-transcendental messages flooding us. The soul is analyzed transcendentally, and reference material is provided to help all, especially youths, to not be so suggestible and gullible. Until this is done, the Church will always come in second to the suggestibility experts of current information technology

(If not with this article, mentioned reference material will be provided upon request from Sam@DocNigro.com. Just ask for "And Satan Turned Into An Angel of Light", for "YUK the Press and Media," for Chapter 12 on "Gifts of the Holy Spirit, Virtues and Sin" from my book Happy Ending, for "The Ten Commandments of CounterSecularization," for the poster "Why Burn A Flag When You Can Burn A Newspaper," for "The Journalism Ethics and Public Service Award," for "Ideas: You Are What You Think," and for "The Lack Of Survival Stress.")

Problems today for the Roman Catholic Church devolve to one major sin of omission: the failure to adjust and cope with information technology, a problem first addressed in 1994 by my pamphlet "And Satan Turned Into An Angel Of Light." The problem persists. One report says that one-third of raised Catholics do not remain in the Church, while the dearth of vocations to priesthood and religious life speaks for itself...and the reason is that the five decade culture of information technology suggests (seduces to) other ways of thinking and living ("Seduction" is almost always equivalent to "suggestibility" in this article). Indeed, with the flood of messages and suggestions from the world wide web, one hardly knows what to read much less what to believe.

To counter this, I now offer a Suggestibility Prevention Program, not to stop suggestibility itself which would be impossible, but to help all learn to avoid being suggested to evil i.e., to avoid being seduced to sensationalism, emotion, unreason, fantasy and non-being by the mass media of pretendvision (television, movies and internet) and of liarpresses (the liberal press) all without allegiance to much more than disgust, death, sex, and evil (the pursuit of non-being).

The contemporary press and media are generally nothing more than suggestibility machines and manipulation gadgets, used to get people to believe and do what the owners of the press and media want and are willing to accept. Those in charge of these mind control monstrosities are usually "liberals" meaning they are relativists i.e., open-minded for anything except that which they really do not like, at which time they become fascists causing the named "Free Flow Of Information Act" to be a joke. But "suggestibility," their suggesting, is the name of the game, and

Volume 5 Issue 2 - 2016
Dr. Samuinion
Retired, Assistant Clinical Professor Psychiatry, Case Western
Reserve University School of Medicine, USA
*Corresponding author: Dr. Samuel A Nigro M.D, Retired,
Assistant Clinical Professor Psychiatry, Case Western Reserve
University School of Medicine, 2517 Guilford Road, Cleveland
Heights, Ohio 44118, USA, Tel: 216 932-0575; Email:
sam@docnigro.com
Received: October 15, 2015 | Published: January 27, 2016

their brutal intolerance of that with which they disagree is never seen as self-contradictory and self-discrediting to their eager socalled openness (liberalness) to all things.

Actually, suggestibility is proof of the Bible story of Adam and Eve. The serpent suggested (advertised, sold) the idea that they would be like God and live forever if they ate the forbidden fruit when, without realizing, they already were made in the "image and likeness of God" and if living rightly would already live forever. Thus, as satanically suggested, they made the wrong choice and broke the up to then automatic transcendental existence for all humanity. "Choosing wrong" became possible, and suggestibility (the convincing of another by rhetorical power), first offered in the biblical story, became part of human nature, also proving that some myths are true. Basically, Original Sin continues as man's suggestibility, and it haunts us day in and day out, especially with the advent of current slick information technology flooding us in our homes, cars, theaters and everywhere. Information technology is a "look at me", "believe me," "do what I show and tell" suggestibility contest (and, more often than not, if we see it, we will do it, proving Original Sin). Information technology today has only a facade of logic and cares little for "reality" except to occasionally claim it.

It is evident that ever since Adam and Eve, humans have competed for what and whom to believe. We all offer suggestions, this paper being an example of such. However, being reminded that we are in a continuous showbiz circus of suggestions can reduce impulsiveness and thoughtlessness in making choices about what to believe and do. Further helpful is the truism that a major way to confirm the acceptability of any suggestion is that the ideas offered can be applied to themselves, something rarely true outside of what is compatable with Natural Law, the metaphysics of St. Thomas Aquinas and the Transcendentals. 
Given all that, it is time for Suggestibility Prevention Programs to help everyone understand that we are being suggested to, manipulated, and shamelessly influenced to believe and act in certain ways never more enticing, seductive, and slick than with and by the contemporary press and media imposing what is paid for and what is demanded by whoever is paying. Without proper understanding of this, people have been and will be suggested to do almost anything-from running around naked to running concentration camps and everything in between.

Especially, youth and the immature are prone to be suggested into all sorts of anti-transcendental aspects of existence which do little for the common good and are against individual positive development. Finally, the flagrantly stupid self exposures rampant on the world wide web are unimpeachable proof of the need for Suggestibilty Prevention Programs. Something is clearly needed to better prepare all youths, including the college and university bound, for the pandemic of liberal assaults on life, family, country, God, and virtue.

\section{Twelve Elementary Suggestions to Prevent Suggestibilty}

Beginning in grade schools, calculated educational efforts and experiences need to be taught on a regular basis about "not being so suggestible or gullible." Consistent with that, the following suggestions are made:

1. A newspaper or media story would be brought in daily and reviewed with an effort to identify suggestions if not errors in the article and discern what the writer was trying to get you to believe and do. An atmosphere of healthy doubt will occur in the discussions of alternative ways of presenting and interpreting the information provided. The universal questions will be: Why is this information presented this way; what do they want you to buy; and is it junk food or junk ideas? These questions should be automatic with every statement in the press and media not only in newspapers but in what is seen in television, movies and on the internet. Make no mistake about it: Every word in the press and media has been chosen to suggest something to you.

2. Suggestibility Prevention Commandments to be learned:

i. Do not be so impressionable.

ii. Do not be so gullible.

iii. Do not be a "monkey see, monkey do copycat" - you are not a monkey.

iv. Celebrities are fakes. Actors are fakes. It takes them hours to look that way and they get paid to carry on like that. Consider none of it to be real. Be who you are. The seeking and promoting of nonbeing is evil unless known to be entertainment.

v. Believe nothing on television, in movies, on internet or in newspapers without two confirmations. The most you can usually hope for is to be entertained.

vi. Do not believe, do anything, or imitate except what is true, one, good and beautiful no matter what is done, offered or believed by others.

vii. Materially, you are what you eat. But spiritually you are what you think and will become what you think and do ... so think matter, identity, truth, oneness, good and beauty, and all will be well or better.

viii. In the long run you will get for eternity (in heaven, purgatory or hell) whatever you have thought and done ... so think and do what is true, one, good, and beautiful. You are what you think, and you will get forever in justice in an afterlife what you think and do on earth as a reward or punishment as the case may be-so do what is transcendental so you will get what is transcendental!

ix. Boycott all antispiritual dehumanizing degrading anti-nature glitzy nonsense from the uncivilizing unreliable press and media. Do not spend your life doing, thinking, or promoting unreality or nonbeing.

x. Do not be suggestible. You are not missing a thing. Do the transcendentals and avoid evil!

These prevention commandments are to be learned and discussed thoroughly.

3. On a monthly basis, review portions of "Satan Turned Into an Angel of Light..." so that the entire pamphlet is covered each year.

4. On a quarterly basis, review portions of "Yuk, the Press and Media." This book provides the vocabulary and imagery necessary to prevent the ethnic cleansing routinely offered by the slick press and media.

5. Because of the flagrant exploitation of human sexuality, the dysphoric but exciting, the vulgar but sensuous, the antisocial but exhilarating, the destructive but satisfying, and the antiplanet but self-inflating sexuality imposed by the press and media, more than anything, needs defusing and reduced to elementary understanding in order for people not to be suggestible and not to have to imitate all the unnatural polluting crudities seen. Sex sensationalism will never be minimized so it must be defused by repetitive clarifications that, for all the animal kingdom of which man is a part, sex is for reproduction. Period. When not for reproduction, sex is animal cruelty, a form of excretion, or non-being. Any exceptions are isolated deviations readily discerned as abnormalities from environmentally sound nature. Thus, contemporary non-marital human sexuality flooding the world is behavioral pollution and, pure and simple, against the animal kingdom, the planet and nature. Non-reproductive sexuality is a form of excretion better known as "sexcretion," which is to dediaper each other and bring one another to "squirt/moan" or "slime/squeal" anyway possible. Such sex polluting ideas are primarily due to the press and media suggesting ejaculation (a simple neurological reflex) and its anticipation as the ultimate 
all-encompassing life experience to vulnerable excitable suggestible people, especially youth. To offset that, the attached Addendum: "1 Page Suggestibilty Education And Sex Education For All People" needs yearly promulgation in all schools. To allow this simple ejaculation reflex to be supreme ruler of the brain and body is absolute idiocy even if everyone suggests that should be the case.

6. Suggestibilty is made more salutary if the meaning of the soul is taught and reminded of daily as the personification of one's Transcendentals. The soul is the personification of the permanent things in our existence. That is, all being at the human level needs Transcendental awareness and Transcendental projection because that is the only way to "save" our souls. All else, all else, is impermanent.

The soul contains six discernible components of being known as Transcendentals: the embraced material substance (res), forming identity (aliquid), truth (verum), oneness (unum), good (bonum) and beauty (bella). To relate in tune with the universe and all Nature, to be Catholic encompassing all possible, to be genuinely free, and to "save one's soul," each of the six dimensions listed of the soul needs to be enthusiastically promoted and projected at all times. The Transcendentals are basic elements to genuine humanbeingness:

I. The embraced-by-the-soul material substance (res) of one's being must be fostered, cared for, and engaged in and with the world. Res is our body. It must be used. It is our matter and our organizing fathering capacity.

II. One's forming identity (aliquid) must be established and allowed full and free expression in confluence with the essence of humanity. Aliquid is the activating gentle mothering capacity, giving identity and essence to all.

III. The truth (verum) of one's being must be kept consistent, conforming and in social reality confluence with one's self, one's family, one's community, one's species, the planet and the universe.

IV. The oneness (unum) of a being is the unifying of desirables into a totality of being as oneself relates from family to the universe.

V. The good (bonum) of one's being must be projected in confluence with Natural Law. That is, Natural Law as it is perceived and understood must be followed and chosen. One must be environmentally sound not only in terms of the planet and nature but in terms of one's own personal beingness as part of that environment. Human beings as individuals must be environmentally and behaviorally real and consistent with nature. Bonum is choosing transcendental work and life.

VI. One's beauty (bella) must be projected in confluence with the uplifting dimension of being. That is, the best must be brought out in one's self and in those capable of being influenced. Bella is the elevating and ascending of self and others.
These six components of our souls, these Transcendentals (material substance, identity, truth, oneness, good and beauty), are how each human being needs to grasp the awareness of and to project in consciousness the transcendental embracing of all one deals with by intellect and will. In total, these six Transcendentals personified are one's soul embracing the body as a composite person being. The soul contains not only our body but in equal proportion an identity, a truth, a oneness, a good, and a beauty, all of which need equal attention and expression. When one starts treating all of them as our body (res) is treated, the whole universe changes and we become immune to non-being (and able to resist the pursuit of non-being, which is evil, overwhelmingly offered and suggested by most of the press and media).

7. Something must be provided, offered, imposed, suggested, of course, which is transcendentally sound to functionally replace all the exciting glitz, the psychological nonsense, and the bewildering confusing idea pollution continuously flooding the suggestible world. Not only must all be warned and trained not to be easily suggestible, but something must be offered to take the place of what is seen and heard-not only to replace it in space but with insight, understanding, and functional positive alternatives, i.e., to replace non-being with being itself. Thus I recommend "Chapter 12: Gifts of the Holy Spirit, Virtues and Sin" from my book Happy Ending. To know what sin is, to know what salutary habits are, and to know the influences to virtue, is to be able to recognize evil (sin) when being suggested, the appropriate methods of coping (virtues), and the motivation to do what is transcendental (the Gifts of the Holy Spirit). In fact, almost all psychology can be replaced by this chapter which is more valuable than any suggested psychological fantasized processing. (Almost all psychology is irrelevant non-being when compared to the knowledge of sins, virtues and the Gifts of the Holy Spirit; because whenever psychology provides valid interpretations, documentations and actions, the meanings and significance thereof are fundamentally and incontrovertibly in terms of sin and virtue, a fact usually overlooked, ignored or denied. Even with volumes of Freudian or scientific data, all psychology can be replaced, in the final analysis, by a knowledge of sin, virtue and the Gifts.) In short, the information in these pages should be an annual educational experience because they will be more explanatory and functional for the common good and for individual positive development. Truly, "humanbeingness" cannot be understood without understanding sin, virtue and the Gifts of the Holy Spirit.

8. The Ten Commandments of Counter Secularization are to be studied learned and taught yearly. These are attached or available by email as a separate article.

9. A work of art poster "WHY BURN A FLAG WHEN YOU CAN BURN A NEWSPAPER?" is offered as a classroom aid. It is the first "PRESS ED" ever offered anywhere. It provides all the vocabulary and information needed to understand and cope better with the press and media. It was first promoted in 1991 as something to "immunize...to cope with PAMS... 
the Press-And-Media Syndrome (the most devastating mind-killing disorder in the history of the world)." An enlargement of this poster should be in every classroom.

10. The JOURNALISM ETHICS AND PUBLIC SERVICE AWARD was begun in 1994. It conveys information exhaustively helping to understand and diminish the suggestibility of the press and media. Never has the press and media been more accurately described. This is an essential study deserving distribution to all in every school on an annual basis. Actually, almost all in the press and media should be mockingly referred to as "American Royalty." The New York Times and Hollywood represent the castles, and all in the press and media in general represent the worst of all kings and queens who ever lived. They have ordained themselves for the people as divine providers of outlandish pretenses of justice and charity by unconditional legitimacy and authority to manipulate and suggest their beliefs The American Royalty provide government of the press $\&$ media, by the press \& media and for the press \& media Never call any of them "journalist x" or "actress/actor x" or "editor $\mathrm{x}$ " and so on, but "royalty $\mathrm{x!"} \mathrm{It} \mathrm{is} \mathrm{"The} \mathrm{New} \mathrm{York}$ Times royalty" or "Hollywood royalty" - they know it all, are in charge of everything, and are never wrong-THEY ARE ROYALTY in the worst sense, and they should NEVER be allowed to forget it.

11. The article "Ideas: You Are What You Think" describes how we turn into that which we see, hear and believe, obviously true if one follows those who left the Church for the suggestions of the mass media.

12. Finally, Suggestibility Prevention Programs are needed to enable all to be able to focus on what is really salutary. The distractions from the press and media are so overwhelming that people have lost the ability to participate rather than just mindlessly wait for entertainment. The passivity of doing nothing, of thinking nothing, and of inactive thoughtless watching flickering lights and reading ink smudges without really participating in an activity, is detrimental to one's being. A good example of that is the losing of participation in the Mass by passive numbness as described in "The Lack Of Survival Stress" available by e-mail.

\section{Conclusion}

Recognizing and promoting A Suggestibility Prevention Program will be to move to the new world, the new age, the new millennium, the new man (male and female), and to assist in the prevention of suggestibility for all that is antitranscendental. And maybe the Church will be able to offset the avalanche of seductive suggestions from the press and media. Furthermore, the projection of one's personal Transcendentals will enhance the bursting forth of peace on earth. By suggestibility prevention, people will be better immune to the Culture of Disgust and the Age of Anathema both characterized by labial linguistics, proctological exuberance, flirtation with feces, boobsolatry, phallic abuse, psychological hubris, willful entropy, and violence ... in other words, the defeat of the Mortuary Life and escape from "the fallen West" and from "the pagan (demanding agreement to non-being) non-West." So stand aside to protect your own but vigorously challenge all suggestions against Transcendental life, taking comfort in your loneliness, because while the mass media gives little, the rain Baptizes, the wind gives Penance, the bright warm sunlight gives Holy Communion, the cold gives Confirmation, the heat gives Extreme Unction, the lightning gives Holy Orders, and the thunder gives Matrimony. By the Transcendentals, suggestibility becomes salutary and the Sacraments are everywhere; the Incarnation is completed; Redemption is in hand; and Resurrection is just around the corner. But you will hardly ever get any of that from the press and media but a myriad of suggestions for non-being. That is, all sorts of non-being are offered by the mass media seducing all from the transcendental life,...and, once again, the pursuit of non-being is evil. The more evil one does, the more one's being is annihilated and one is converted into that black hole of negative nothingness wherein one repeats for eternity against oneself all the evil (promotion of non-being) one has perpetrated while on earth. But by following and living the Sacraments, one's identified matter flows on a transcendental conduit of truth, oneness, good and beauty, to and through eternity. All you have to do is reject Original Sin by not being suggestible to non-being and what is not real. And, then one can relax knowing that Easter is coming.

You are what you think. You will get what you do. Be transcendental not suggestible. A Suggestibilty Prevention Program is needed. 